\title{
Effect of aqueous extract of cocoyam leaf (Xanthosoma sagittifolium) on growth performance of broiler chickens fed full-fat Soya bean
}

${ }^{1}$ Ebenebe, C. I., ${ }^{1}$ Mmadubugwu, C. A. and ${ }^{2}$ Ogbu, O. C.

${ }^{\prime}$ Department of Animal Sci. and Technology Nnamdi AzikiweUniversity Awka Anambra State, Nigeria.

${ }^{2}$ Department of Agricultural Technology Federal Polytechnic Oko Anambra State, Nigeria.

\begin{abstract}
Corresponding author: ci.ebenebe@unizik.edu.ng

This study evaluated the effect of aqueous extracts from cocoyam leaf on the growth performance of broiler chickens fed full-fat Soya bean. The study was carried out with seventy-two (72) day old broiler chickens in a completely randomized design. The seventytwo (72) broiler chicks were randomly assigned into four groups (T1, T2, T3 and T4), each treatment had (3) birds per replicate. The T1 which was the control, contained Og of aqueous extract of cocoyam leaves while the birds in T2, T3 and T4 were offered aqueous extract of cocoyam leaves at $100 \mathrm{~g}, 150 \mathrm{~g}$ and $200 \mathrm{~g}$ per 6 liters of water, respectively. The test ingredients were analyzed for nutritional and phytochemical composition. Data was collected from the broiler chickens' daily feed intake, feed conversion ratio, specific growth rate, body weight gain and daily weight gain. There were no significant differences $(P>0.05)$ on the feed intake, daily weight gain, feed efficiency, feed conversion ratio, initial and final body weights of the broiler birds. However, total water and mean daily water intake differed significantly (P>0.05). The extract administered groups (T2, T3 and T4) had lower water intake as the quality of cocoyam leaves increased. The significant variations in the water intake as the quantity of cocoyam increased may be attributed to anti-nutrient factors (tannins) found in the leaves. The cocoyam leaves are rich in nutrients when assessed by the proximate and mineral composition. It can serve as a feedstufffor livestock. Cocoyam leaves extracts should be used with caution due to the anti-nutritional factors present in it. It is therefore safe to recommend 100-150g of cocoyam leaves/ Glitres of water for broiler chickens without any negative impact on growth rate of the broiler chickens.
\end{abstract}

Keywords: Broiler chickens, Cocoyam leaves, Extracts, Growth

\section{Introduction}

Animal protein is essential for human health and development but its availability for human consumption especially in developing countries has become a mirage (Omoikhoje, 2017). The Nigerian population and the overall demand for animal protein is growing at an alarming rate while the current animal protein demand is on the increase. This portrays a situation of hunger for animal protein and in order to effectively combat this malnutrition and under nourishment; FAO (2010) recommended a minimum of $65 \mathrm{~g}$ of protein per person per day of which $35 \mathrm{~g}$
(53.8\%) must come from animal sources (Lamorde, 2008). According to Adegbola (1990) and Layang et al. (2014) only 8.29 of animal protein is consumed per person per day by an average Nigerian which indicates that about $60-80$ percent of Nigerians are malnourished. The problem of animal protein production shortage in Nigeria is attributed to the fact that the human population is growing at $2.8 \%$ per annum while that of animal population is growing at $1.8 \%$ per annum (Ilu et al., 2016). Therefore, only an optimum animal production will help to alleviate this situation. Besides, massive production of 


\section{Effect of aqueous extract of cocoyam leaf (Xanthosoma sagittifolium)}

prolific animals like swine is limited by challenges of religious and socio-cultural prohibitions. Meanwhile, poultry animals and products have been considered to be one of the options in Nigeria for reducing the incidence of this malnutrition particularly animal protein shortage in diets of populace because of its ability to provide a good supply of protein, essential vitamins and minerals, regulating cholesterol and blood pressure. However, these poultry birds that have expensive feed and feeding materials brings about impediments on the increase in animal protein supply. Apart from the problems associated with production cost, poultry meat is also associated with fat deposition. In recent times corn/soya feed mix has been the practice in most feed formulating industries (NRC, 1994), but the fat related diseases and disorder such as atherosclerosis, type II diabetes, and cardiovascular diseases (Yasuko et al., 2010) resulting from such meat is making a lot of people to search for meat with less fat content (lean meat). Thus, the need to access the possibility of minimizing fat deposition using readily available feed additives. Cocoyam leaves appear to have the potential to reduce the fat deposition in animals raised on corn/soya mixture.

\section{Material and methods Experimental site}

The research was undertaken at the poultry unit of teaching and research of Department of Animal Science and Technology, Faculty of Agriculture, Nnamdi Azikiwe University, Awka, Anambra State, Nigeria. Awkalies between latitude $6.24^{\circ} \mathrm{N}$ and $6.28^{\circ} \mathrm{N}$ and longitude $7.00^{\circ} \mathrm{E}$ and $7.08^{\circ} \mathrm{E}$ on the South Eastern part of Nigeria, the climate is the tropical wet and dry type with a clear season, the mean daily maximum temperature is usually $27^{\circ} \mathrm{Call}$ over the year although it could reach $34^{\circ} \mathrm{C}$ in March and lowest during the harmattan months of December and January (Ezenwaji et al., 2013).

\section{Sourcing and processing of experimental materials.}

Seventy-two (72), one day-old Abor acre boiler birds were procured from ZARTECH farms Ibadan.Brooding and acclimatization lasted for two weeks before feeding the birds with experimental diets. Routine medications, commercial feed and antibiotics were given within this period. The cocoyam leaves were sourcedfrom local farmers from Uga in Anambra state and air dried for some days. Thereafter, the dried plant materials were ground using a locally fabricated hammer milling machine and then stored in an airtight container. $100 \mathrm{~g}, 150 \mathrm{~g}$ and $200 \mathrm{~g}$ of ground air dried plant material powder were separately macerated in the drinking troughs with each containing six litres of water. The aqueous extracts of cocoyam (Xanthosoma sagoltifolium) leaves were obtained by sieving the sediments from the liquid using a sieve.

The full fat soya been used for the trial was purchased from Nnobi village market in Anambra state. Dirt's and debris were handpicked, thereafter, the full- fat seed was heat treated by roasting in an open pan for forty-seven (47) minutes to reduce antinutritional factors and enhance digestibility. The roasted full fat soya was further processed by milling using a locally fabricated milling machine model before incorporation into experimental diets.

\section{Experimental design}

The seventy two (72) broiler chicks were randomly assigned into four groups (T1, T2, T3 and T4), each treatment had (3) birds per replicate, in a completely randomized design (CRD). The T1 which served as control contained $0 \mathrm{~g}$ of aqueous extract of cocoyam leaves while the birds in $\mathrm{T} 2, \mathrm{~T} 3$ and T4 were offered aqueous extract of 


\section{Ebenebe, Mmadubugwu and Ogbu}

cocoyam leaves at $100 \mathrm{~g}, 150 \mathrm{~g}$ and $200 \mathrm{~g}$ per 6 liters of water, respectively. The experimental diet was prepared using full fat soya bean to ensure that the broiler chicks were given feed that will allow fat deposition. The gross compositions of the diets were shown in Table 1 . While the proximate as well as the mineral composition of the cocoyam leaves were shown in Table 2.

\section{Data collection}

Data was collected from the initial body weight of the bird before feeding of the experimental diet with sensitive balance (MODEL SF400). The birds were subsequently weighed on a weekly interval, till the end of the experiment.

Data was collected on daily feed intake as thus by deducting quantity of left over from quantity of feed given.
Feed conversion ratio was deducted by dividing quantity of feed consumed with weight gain.

Feed efficiency was calculated by dividing body weight gain with quantity of feed consumed.

Specific growth rate was deducted from final weight minus initial body weight all divided by time Interval.

Body weight gain was calculated as; Final body weight - Initial body weight.

Daily body weight gain was deducted as thus final body weight - initial body weight divided by number of days.

\section{Statistical analysis}

Data were subjected to analysis of variance design (ANOVA) for a completely randomized design analysis using SPSS computer software package version 2.2.

Table 1: Composition of the experimental diet

\begin{tabular}{lc}
\hline Ingredients & Level of inclusion \\
\hline Maize & 58.00 \\
Full fat soya & 26.50 \\
Fish meal & 4.00 \\
Dry brewer's grain & 5.00 \\
Oil palm & 2.00 \\
Bone meal & 2.50 \\
Lime stone & 0.50 \\
Salt & 0.50 \\
Methionine & 0.30 \\
Lysine & 0.20 \\
Vitamin premix & 0.50 \\
Calculated Analysis & \\
Crude protein & 19.70 \\
Crude fat & 5.60 \\
Crude fibre & 7.55 \\
Ash & 5.13 \\
Nitrogen free extract & 52.59 \\
Dry matter & 90.57 \\
Moisture & 9.43 \\
Gross energy (Kcal/kg) & 2910.76 \\
\hline
\end{tabular}




\section{Effect of aqueous extract of cocoyam leaf (Xanthosoma sagittifolium)}

Table 2: Proximate and mineral composition of the experimental ingredients (cocoyam leaves)

\begin{tabular}{lc}
\hline \multicolumn{1}{c}{ Nutrients } & Composition (\%) \\
\hline Crude protein & 15.53 \\
Crude fat & 9.60 \\
Crude fibre & 17.41 \\
Ash & 11.60 \\
Nitrogen free extracts & 37.71 \\
Dry matter & 91.15 \\
Moisture & 8.15 \\
Gross energy (Kcal/Kg) & 2990.36 \\
Minerals & \\
Magnesium $(\mathrm{mg} / 100 \mathrm{~g})$ & 68.06 \\
Calcium $(\mathrm{mg} / 100 \mathrm{~g})$ & 130.18 \\
Phosphorus $(\mathrm{mg} / 100 \mathrm{~g})$ & 150.40 \\
Sodium $(\mathrm{mg} / 100 \mathrm{~g})$ & 192.06 \\
Potassium $(\mathrm{mg} / 100 \mathrm{~g})$ & 220.01 \\
Iron $(\mathrm{mg} / 100 \mathrm{~g})$ & 0.07 \\
Zinc $(\mathrm{mg} / 100 \mathrm{~g})$ & 0.08 \\
Copper $(\mathrm{mg} / 100 \mathrm{~g})$ & 0.04 \\
Manganese $(\mathrm{mg} / 100 \mathrm{~g})$ & 0.05 \\
\hline
\end{tabular}

Table 3: Phytochemical composition of the cocoyam leaves

\begin{tabular}{lc}
\hline Parameters & Composition $\mathbf{( m g} / \mathbf{1 0 0 g})$ \\
\hline Flavonoids & 2.90 \\
Tannins & 1.28 \\
Alkaloids & 9.60 \\
Steroids & 0.61 \\
Phenols & 230.40 \\
Cyanide & 0.21 \\
Phytate & 1.19 \\
Oxalate & 0.70 \\
\hline
\end{tabular}

Table 4: Mean values of growth performance of broiler chicken administered aqueous extract of cocoyam leaves

\begin{tabular}{lrrrrr}
\hline Parameters & T1 & T2 & T3 & T4 & SEM \\
\hline Initial body weight (g) & 223.56 & 258.77 & 228.06 & 241.33 & 0.57 \\
Finial body weight (g) & 1246.39 & 1195.77 & 1238.89 & 1182.76 & 1.18 \\
Daily weight gain (g) & 24.35 & 22.30 & 24.07 & 22.08 & 0.52 \\
Total feed intake (g) & 3329.89 & 3197.17 & 3229.22 & 3325.50 & 1.69 \\
Daily feed intake (g) & 79.28 & 76.17 & 76.88 & 79.1 & 0.36 \\
Feed conversion ratio & 2.67 & 2.68 & 2.61 & 2.96 & 0.11 \\
Feed efficiency & 0.31 & 0.29 & 0.31 & 0.26 & 0.02 \\
Specific growth rate & 0.17 & 0.16 & 0.16 & 0.16 & 0.19 \\
Total water intake (l) & $2.76^{\mathrm{a}}$ & $2.51^{\mathrm{b}}$ & $2.32^{\mathrm{c}}$ & $2.07^{\mathrm{d}}$ & 0.48 \\
Daily water intake (l) $^{\mathrm{a}}$ & $0.15^{\mathrm{a}}$ & $0.14^{\mathrm{b}}$ & $0.13^{\mathrm{c}}$ & $0.12^{\mathrm{d}}$ & 0.21 \\
\hline
\end{tabular}

Means with superscripts ${ }^{\mathrm{a}, \mathrm{b}, \mathrm{c}}$ and ${ }^{\mathrm{d}}$ are significantly different. 


\section{Ebenebe, Mmadubugwu and Ogbu}

\section{Results and discussion}

The nutrient composition of the test ingredient (cocoyam leaves) in Table 2 indicated that the test ingredient has crude protein level of $15.53 \%$, crude fat of $6.60 \%$, crude fibre of $11.41 \%$, ash content of $8.15 \%$, nitrogen free extract of $37.7 \%$, dry matter content of $91.15 \%$ and moisture content of $8.15 \%$. These values were quite contrary to the reports of Apata and Babalola (2012). These variations in the proximate compositions of cocoyam leaves may have being influenced by soil nutrients, soil type and location, where the cocoyam were sourced. However, the mineral composition of the cocoyam leaves used in this study presented in Table 2 shows that the cocoyam leaves used in this study is rich in Magnesium ( $68.06 \mathrm{mg} / 100 \mathrm{~g}), \quad \mathrm{c} \mathrm{a} 1 \mathrm{c} \mathrm{i} \mathrm{u} \mathrm{m}$ $(130.18 \mathrm{mg} / 100 \mathrm{~g})$, phosphorus ( $192.06 \mathrm{mg} / 100 \mathrm{~g}$ ) potassium ( $220.05 \mathrm{mg} / 100 \mathrm{~g})$ and sodium $(192.06 \mathrm{mg} / 100 \mathrm{~g})$. These reports collaborated with the findings of Opara (2003) Chukwu et al., (2008) Ekwe et al., (2009) and Lim (2016). The phytochemical composition of cocoyam leaves is shown in Table 3. It is obvious that cocoyam leaves is high in Alkaloids $(9.60 \mathrm{mg} / 100 \mathrm{~g})$ and phenols $(230.40 / \mathrm{mg} / 100 \mathrm{~g})$. The result of the phytochemical composition of cocoyam in our study were similar to Apata et al., (2012) study reports on cocoyam. These high levels of phenols in cocoyam can be put to effective use in the pharmaceutical and food industry, since it is an important antioxidant (Mmadubugwu et al., 2017).

The effect of aqueous extracts of cocoyam leaves on the mean growth performance of broiler birds is shown in Table 4. There were no significant difference $(\mathrm{P}>0.05)$ in the feed intake, daily weight gain, feed efficiency, feed conversion ratio, initial and final body weights of the broiler birds. However, total water and mean daily water intake differed significantly $(\mathrm{P}>0.05)$. While the extract administered groups (T2, T3 and T4) had lower water intake as the quality of cocoyam leaves increased. These non-significant differences $(\mathrm{P}>0.05)$ in the feed intake, feed conversion ratio, feed efficiency as well as specific growth rate of broiler birds given aqueous extract of cocoyam leaves, is in line with the reports of Giang (2010) who used cocoyam leaves and stem on ducks. The significant variations in the water intake as the quantity of cocoyam increased may be attributed to anti nutrient factors (tannins) found in the leaves. Tannins according to Haslam (1989) and Ndymugyenyi (2016) are astringent, bitter tasting plant poly phenols which can reduce free water intake.

In conclusion, the cocoyam leaves are rich in nutrients when assessed by the proximate and mineral composition. It can serve as a feedstuff for livestock. Cocoyam leaves extracts should be used with caution due to the anti-nutritional factors present in it. It is therefore safe to recommend 100-150g of cocoyam leaves/ 6litres of water for broiler chickens without any negative impact on growth rate.

\section{References}

Apata, D. F. and Babalola, T. O. 2012. The use of cassava, sweet potatoes and their byproducts by nonruminants. International journal of food science and nutrition engineering, 2(4): 54-62.

Chukwu, G. O., Ekwe, K. C. and Anyaeche, S. 2008. Cocoyam production and usage in Nigeria National Root Crops Research Institute (NRCRI). News Bulletin. 1pg. 2.

Ekwe, K. C., Nwosu, K. I., Ekwe, C. C. and Nwachukwu, I. 2009. Examining the underexploited values of cocoyam (Colocasia and 


\section{Effect of aqueous extract of cocoyam leaf (Xanthosoma sagittifolium)}

Xanthosoma spp) for enhance household food security, nutrition and economy in Nigeria.

Ezenwaji, E. E., Okoye, A. C. and Awopeju, A. K. 2013. The relative contributions of climatic elements and environmental factors to flooding in Awka urban area, African journal of Environmental science and technology, 7(8) 804814

FAO, 2010. Agribusiness Handbook: Poultry meat and eggs. Investment Centre division. FAO, Rome Italy.

Giang T. N. 2010. Effect on the performance of common ducks of supplementing rice bran with taro (Colocasia esculenta) foliage. A thesis submitted to the department of Animal Science University of Agricultural Sciences Sweden.

Ilu, I. Y., Frank, A. and Annatte, I. 2016. Review of the livestock/ meat and milk value chains and policy influencing them in Nigeria. $A$ publication by the Food and Agriculture Organization of the UnitedNations and the Economic Community of West African States. 1-6.

Inyang, H. B., Adebayo, E. F. and Anyanwu S. O. 2014 . Consumption of animal products in Adamawa state; An Empirical Analysis, Journal of studies in social sciences 7(1) 42-43.

Larmorde, A. G. 2008. Scenario building for the Nigerian livestock industry in the $21^{\text {st }}$ century proceedings of the joint silver anniversary conference of the Nigerian Society for Animal Production (NSAP) and West African Society for Animal Production (WASAP) Inaugural conference, 21-26 March, 127-134.
Lim, T. K. 2016. Edible medicinal and nonmedicinal plants .Springer publications New Yolk London.

Ndyomugyenyi, E. K. 2016. The potential of Jackfruit (Artocarpus heterophyllus) and Java Plum (Syzygiumcumini) seeds as feed poultry.

National Research Council 1994. Nutrient Requirements of poultry, $9^{\text {th }}$ revised edition. National Academy press, Washington, D.C.

Omoikhoje, S. O., Imade, J. E. and Odiase, M. O. 2017. Nutritive value of pigeon pea (Cajanus Cajan) seeds soaked in wood ash extract as protein feedstuff for broiler chicken production. Nigerian Journal of Animal Production. 44(2)101.

Opara, L. U. 2003. Edible aroids; Post harvest operations Rome, Italy; Food and Agriculture Organization of the United Nations.

Yasuko, M. Shigenobu, M. and Tohru, F. 2010. Chapter 10: Preference for high-fat food in animals in fat dictation; taste, texture and post ingestive effects. CRC press Taylor and Francis

Received: $12^{\text {th }}$ August, 2018 Accepted: $9^{\text {th }}$ February, 2019 